\title{
Charms, etc., Figured on Plate IX.
}

\section{R. C. Maclagan}

To cite this article: R. C. Maclagan (1903) Charms, etc., Figured on Plate IX., Folklore, 14:3, 298-300, DOI: 10.1080/0015587X.1903.9719364

To link to this article: http://dx.doi.org/10.1080/0015587X.1903.9719364

$$
\text { 曲 Published online: } 06 \text { Feb } 2012 .
$$

[6] Submit your article to this journal

$$
\text { Џlll Article views: } 1
$$

Q View related articles $\longleftarrow$

Citing articles: 1 View citing articles $\sqsubset$ 
by red string, from the person, or out side a bed curtain, or tied to the wrist of a baby; or a number of cash from the reigns of different emperors may be placed under a bridal bed. Some of the cash so used and exhibited are current in Pekin only.

The cash szoord shown is too familiar to need description. It may be noted that many brought home by travellers are not genuine charms, but only copies made for sale to tourists as curios. The cash sword is specially valued as a protection for a bridal bed, outside the curtains of which it is hung with its blade parallel to the horizon. The last charm shown, ma tsien or horse money, is blank on one side, and on the other shows a horse with the inscription "shadow of the footprints" (a wish for a safe and speedy return).

A. R. WRIGHT.

Charms, etc., figured on Plate IX.

$$
\text { (Ante, p. 210.) }
$$

I. Having been informed that a gentleman living at Bonarbridge, in Sutherlandshire, was in possession of three stones which were supposed to confer magical powers on a woman who died but three years ago, I endeavoured to get them, in order to exhibit them to the Society. Their owner, while admitting that the stones have no power of their own, attaches some value to them as curiosities. Having got them on loan for a few days, I examined them, and had then photographed. These stones are the three shown on the spectator's left. They are water-worn nodules of sandstone, the larger one of a red stone, the other two, shaped like eggs, of a light grey, spotted with dark brown, as if the spotted portion contained iron. The woman who owned them undoubtedly considered them of value as having some secret virtues. The principal fact recorded about them in the neighbourhood in which she died is that with their assistance she caused the death of the wife of a man who had jilted herself.

II. The centre of the photograph shows what was worn habitu- 


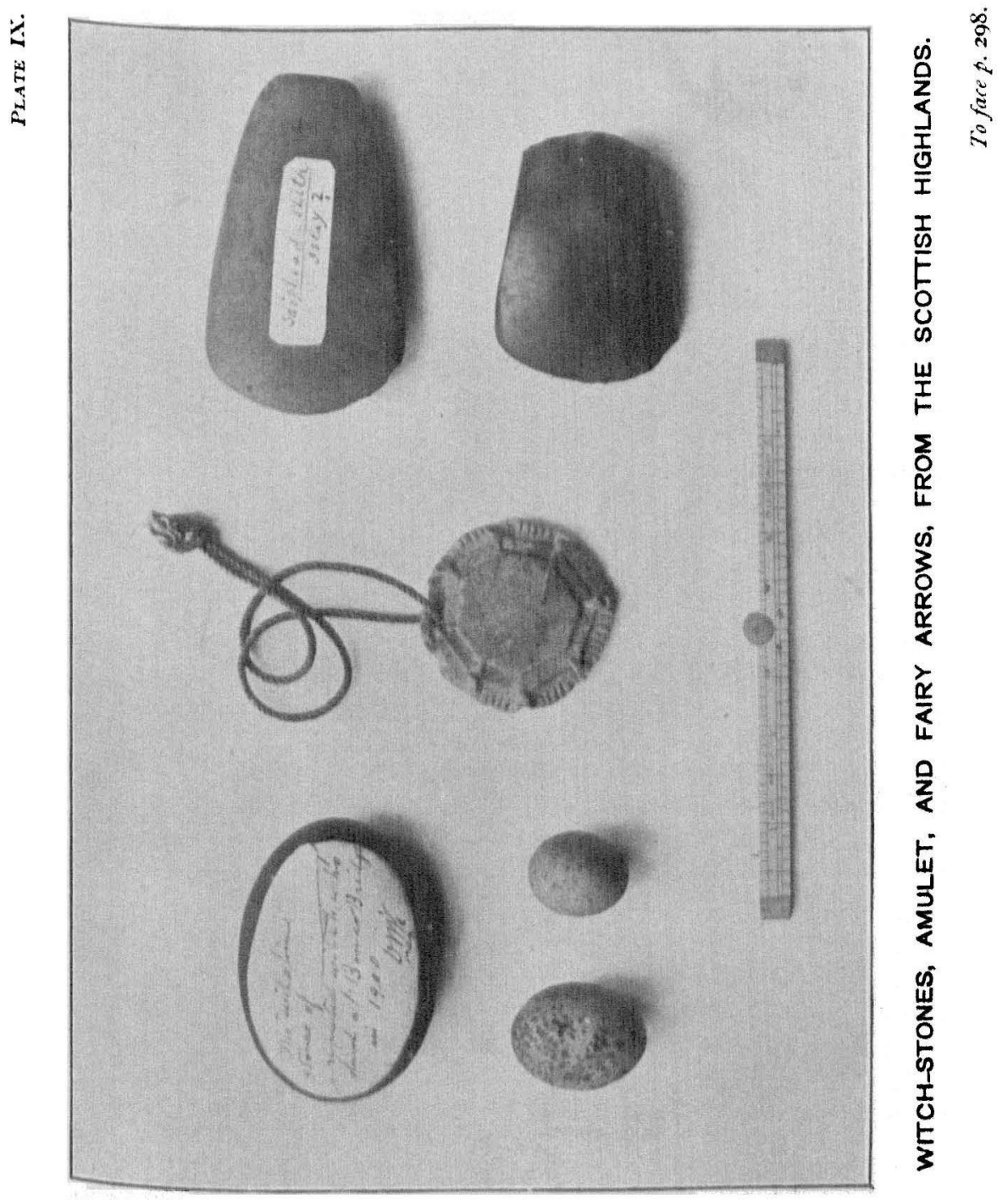


ally by a man known personally to the owner of the witch-stones. He wore it suspended from his neck as a protection against witchcraft. The wearer, D. McL., was a native of Wester Ross, and had great confidence in the efficacy of his talisman. There is no history of how or when he procured it. It is a piece of grey steatite, and, like many pieces of steatite, has pink markings on it. These may have suggested blood-stains. To judge by its appearance and the style of carving, it seems to have come from India, but for what purpose it was originally made no guess is hazarded.

III. On the right of the photograph are two "celts." The lower one is nearly black (basalt?), the upper one is of a very light grey and in perfect condition. Both are of hard close-grained stone. The interest attaching to them is that they are "fairy arrows." They were found at Mulindry Glen, near what appears in the maps as Dun Nosebridge, locally called Nosbreac, Islay. The original owner of them, when handing them to the lady from whom they were received, said " they were in the possession of her father and her grandfather and were always called saigheadan shith and were saigheadan shith." In Eigg these seem to be called Ceapa-Sithein, as if they had been used for blocking something on, as a shoemaker's last is used. In Walker's Historical Memoir on the Armour and Weapons of the Irish, he says (p. 126): "Mr. Owens, the editor of Rowland's MIona Antigua, seems decidedly of opinion that the celt, an instrument so-called from our ignorance of its use, was employed as a sling-hatchet." The date of this essay is 1788 . . Further back still we know of the Leacan Laoich Milidh, "champion's hand stone," described by O'Curry (Manners and Customs, ii., p, 277) as "a half" or modified "flat stone"; "for" leac means a perfectly flat stone, so that leacan must mean a stone partaking somewhat of the flat form." This he identifies with the so-called "celt," and details how it was kept in the boss of his shield and used as a projectile by Fergus Mac Roigh (temp. Cuchullin). As the Islay woman the other day having never seen such an article in use called it, traditionally, a "fairy arrow," so we may consider that the early Gaelic writer was also speaking of what he had seen, but of which the proper use was a subject of conjecture; in fact, that the story was written at a time when celts had become objects of speculation to the curious. 


\section{Uist Bodkin sent for Exhibition (see p 2 ro).}

The bone stiletto sent was used in Uist by a staymaker to make the holes for lacing, about 1820 . The holes, of course, were finished by hand-stitching.

Ross-shire "Chucks" sent for Exhibition (see as before).

For playing this game in the neighbourhood of Applecross they use either five balls made of clay hardened by exposure to the sun, in size like ordinary marbles, or oblate spheroids of about the same bulk.

R. C. Maclagan.

\section{Highland Fisher-Folk and their Superstitions.}

Those who dwell in cities may shrug their shoulders at the superstitions of our fisher-people, but we who often stand under the shadow of our northern cliffs and watch the storm and the darkness gather, and listen to the sad moan of the sea as it accompanies the shrill weird cry of the sea birds overhead, are more in sympathy with them. We can understand how brave and daring seamen can still be the veritable children of nature, for there nature is so immense and we are so small.

Some of the most God-fearing and intelligent fisher-people have a strong strain of superstition, inherited from their pagan forefathers and strengthened by their own uncertain hold on life and the consequent sense of the nearness of the unseen. It is when such men are tossed among the billows, like puppets in the hands of an unknown power, that the tales told them by their forefathers take hold of their imagination, and if they have neglected prescribed observances they vow it shall be for the last time.

Even as in the days when the sea refused to be satisfied till Jonah was heaved overboard, our fishermen do not care for the presence of the clergy in their boats, nor do they even like to meet a clergyman on their way to the shore when going to fish. The Devil is said to be the Prince of the Air, and as the clergy are his enemies, there is some method and compliment in the theory that he likes to give them a good shaking when he has the chance! Meeting a red-haired woman, or a cat, is also unlucky; the cat 